\title{
Morphology of immature stages of Helophorus (Gephelophorus) auriculatus (Coleoptera, Helophoridae)
}

\author{
Yûsuke N. MINOSHIMA ${ }^{1)}$ \& Reiya WATANABE ${ }^{2,3)}$ \\ 1) Natural History Division, Kitakyushu Museum of Natural History \& Human History, 2-4-1 Higashida, Yahatahigashi-ku, Kitakyushu-shi, Fukuoka, \\ 805-0071 Japan; e-mail: minoshima@kmnh.jp \\ 2) Graduate School of Life and Environmental Sciences, University of Tsukuba, Ibaraki, Japan, 1-1-1 Tennodai, Tsukuba-shi, Ibaraki, 305-8572 Japan \\ 3) Environmental Technology Division, Institute of Environmental Informatics, IDEA Consultants, Inc., 2-2-2 Hayabuchi, Tsuzuki-ku, Yokohama-shi, \\ Kanagawa, 224-0025 Japan; e-mail: watanabe.reiya.sw@alumni.tsukuba.ac.jp
}

\author{
Accepted: \\ $27^{\text {th }}$ April 2020 \\ Published online: \\ $15^{\text {th }}$ May 2020
}

\begin{abstract}
The morphology of immature stages of Helophorus (Gephelophorus) auriculatus Sharp, 1884 is described. This is the first description of the larva and pupa of the subgenus Gephelophorus Sharp, 1915. We describe the morphology of the egg-case, all larval stages (first to third instar, including chaetotaxy of the head) and pupa. Morphological transformations between larval instars were examined. Head chaetotaxy was nearly identical between instars. Ventral teeth on the nasale, considered as a useful taxonomic character, were absent in the first instar but well developed in later instars. Chaetotaxy differed among the subgenera Gephelophorus, Helophorus and Lihelophorus in the length and shape of setae on head capsule and maxilla. Pupal morphology was similar to that of previously described pupae: $H$. (Helophorus) aquaticus (Linnaeus, 1758) and H. (Rhopalohelophorus) orientalis Motschulsky, 1860. A key to families of the Hydrophiloidea of Japan based on larval characters is provided.
\end{abstract}

Key words. Hydrophiloidea, Helophoridae, Helophorus, egg-case, larva, pupa, chaetotaxy, endangered species, Japan, Palaearctic Region

Zoobank: http://zoobank.org/urn:lsid:zoobank.org:pub:9D78C2BB-8042-4883-9578-A370E8152D9A

(C) 2020 The Authors. This work is licensed under the Creative Commons Attribution-NonCommercial-NoDerivs 3.0 Licence.

\section{Introduction}

The genus Helophorus Fabricius, 1775 is the only modern member of the family Helophoridae in the water scavenger beetle superfamily Hydrophiloidea (sensu HANSEN 1999). The genus is subdivided into nine subgenera (ANGus 1992, FIKÁČEK et al. 2012b). Phylogenetic relationships among subgenera were analysed by FIKÁČ́K et al. (2012b) using morphological and ecological characters of both extinct and extant species. Adults of $\mathrm{He}$ lophorus are usually detritivorous and aquatic, although some are semiaquatic or even terrestrial (ANGUs 1992, FIKÁČEK et al. 2012b). However, the majority of larvae are predaceous and terrestrial, with the exception of a few species such as the herbivorous larva of $H$. (Empleurus) nubilus Fabricius, 1777 and H. (Eutrichelophorus) micans (Faldermann, 1835) (ANGus 1973, 1992).

The immature stages of Helophorus are relatively well studied, especially the egg cases and larvae of European species (BøvING \& HeNRIKSEN 1938; ANGUs 1973,
1992). Larvae have been described for six of the nine subgenera worldwide (ANGUs et al. 2016). In addition, the Mesozoic species Cretotaenia pallida Ponomarenko, 1977 was described based on a fossilized larva related to Helophorus (FIKÁČEK et al. 2012a). However, little information on larval chaetotaxy of Helophoridae is available. FIKÁČEK et al. (2008) summarized characters of the primary chaetotaxy of the head of $\mathrm{H}$. (Helophorus) liguricus Angus, 1970 to compare hydrophilid and helophorid chaetotaxy. Later, ANGUs et al. (2016) described the larvae of H. (Lihelophorus) lamicola Zaitzev, 1908 and $H$. (L.) yangae Angus, Fikáček \& Jia, 2016 in detail and compared their morphology with that of H. liguricus. The pupal morphology of Helophorus has also been largely unknown. The pupae of H. (Helophorus) aquaticus (Linnaeus, 1758) and H. (Rhopalohelophorus) orientalis Motschulsky, 1860 are the only species in the genus for which the pupa has been described (BøvING \& HENRIKSEN 1938, ARCHANGELSKy 1997). 
Gephelophorus Sharp, 1915 is a subgenus of Helophorus consisting of two species, H. auriculatus Sharp, 1884, the type species of the subgenus from Far East Asia, and H. sibiricus (Motschulsky, 1860) from the Palaearctic and Nearctic Regions (HANSEN 1999). The immature stages of these species have never been described apart from the egg case of H. sibiricus (ANGUs 1973, 1992). The second author has successfully reared Japanese individuals of $H$. auriculatus. The life history of $H$. auriculatus was described by WATANABE et al. (2020); however, its detailed morphology has yet to be described. Morphology of immature stages of $H$. auriculatus is expected to provide information for resolving helophorid systematics and for aiding conservation efforts, as $H$. auriculatus is an endangered species on the Japanese Red List (MINISTRY OF THE ENVIRONMENT OF JAPAN 2019). In this paper, we describe in detail the morphology of immature stages of $H$. auriculatus.

\section{Material and methods}

Specimens examined. Examined immature individuals were obtained by rearing of adults collected from paddy fields in Tsukuba-shi, Ibaraki Prefecture, Japan on November 27, 2017 (two males and three females) and November 15, 2018 (four females and four males). Larvae and pupa were fixed with $70 \%$ ethanol or boiling water and preserved in $70-80 \%$ ethanol in the authors' collection.

In total, 32 egg-cases, 12 first, seven second and eight third instar larvae, and one pupa were examined. Of these, two first, one second and three third instar larvae were cleared and placed on slides for further examination. Some styli of the pupa might have broken during fixation or preparation. We describe the pupa according to the following criteria: the number of styli is symmetrical in a respective segment, and the character state of styli is uniform, i.e. all styli bear an apical seta.

Rearing. Rearing was done by the second author in a laboratory at the University of Tsukuba (Tsukuba, Japan). The rearing method followed ANGus (1973) and was almost identical to that described in WaTANABE et al. (2020). Below, we briefly describe our rearing methods.

Adults were kept in plastic containers and plastic cups filled with mud and dead stems of Oryza sativa from the site of collection and $1 \mathrm{~cm}$ of dechlorinated tap water. Adults were fed Spirogyra algae and fish food (Tetra pleco, Spectrum Brands, Tokyo) containing algae. Egg cases and hatched larvae were then moved to plastic cups with wet filter paper on their bottoms. Larvae were fed daily with approximately $0.03 \mathrm{mg}$ of Tubifex worms or frozen chironomid larvae (Kodawari Akamushi, Aso Tropical Fish, Osaka). The third instar larva that did not feed for a day was moved to a plastic cup with wet peat moss for pupation. All life stages were kept at a constant temperature of $15^{\circ} \mathrm{C}$ and 10 hours light +14 hours dark cycle.

Morphological study. Specimens were examined with the aid of a Leica MZ16 (Leica Microsystems, Wetzlar) microscope and an Olympus BX50 (Olympus, Tokyo) microscope. Illustrations were made using a drawing tube attached to the microscopes; line drawings were prepared using the software Paint Tool SAI (Systemax Inc., Tokyo) and Photoshop CC (Adobe Systems Inc., San Jose). Photographs of larval specimens were taken with an Olympus OM-D E-M1 Mark II digital camera with Olympus M. ZUIKO DIGITAL ED 60mm F2.8 Macro lens and Kenko DG Extension Tube (Kenko Tokina, Tokyo). Composite images were created using the focus-stacking software Helicon Focus (Helicon Soft Ltd, Kharkov). Photographs were edited in Adobe Photoshop Lightroom and Photoshop $\mathrm{CC}$ as needed.

Some larvae were cleared using $10 \% \mathrm{KOH}$ solution (ca. $50 \mathrm{~min}$ at $\left.50^{\circ} \mathrm{C}\right)$ or proteinase $\mathrm{K}(20 \mu \mathrm{l}$ proteinase $\mathrm{K}$ solution and $180 \mu \mathrm{l}$ Buffer ATL, for approximately $24 \mathrm{~h}$ at $55^{\circ} \mathrm{C}$; Qiagen, Hilden). These larvae were either permanently mounted with Euparal (Waldeck, Münster) or temporarily mounted with lactic acid on H-S Slides (Kanto Rika, Tokyo) (ShIRAYAmA et al. 1993) for examination.

Measurements of egg cases were made with a Nikon Multi Zoom AZ100M stereo microscope (Nikon, Tokyo) and microscope imaging software (NIS-Elements 4.2.0, Nikon, Tokyo).

Morphological terminology follows ARCHANGELSKY (1997) and ANGus et al. (2016) for general morphology, FiKÁČEK et al. (2008) and BytTEBIER and TORREs (2009) for chaetotaxy. The following abbreviations are used: AN: antenna; FR: frontale; gAN: group of the apical antennal sensilla; gAPP: group of sensilla on inner appendage of maxilla; gFR: group of sensilla on frontale; gLA: group of the apical sensilla on labial palpus; gMX: group of the apical sensilla on maxilla; LA: labium; MN: mandible; MX: maxilla; PA: parietale; SE: sensorium; - (black square): additional sensillum.

\section{Results}

\section{Helophorus (Gephelophorus) auriculatus Sharp, 1884}

Description of egg case. Egg-cases (Figs 1A, B) oviposited on mud near the edge of water. Egg-case bag-shaped, leaflike mast of greatly variable length; $4.49 \pm 1.15$ (1.77-7.99, $\mathrm{n}=32$ ) $\mathrm{mm}$ [mean $\pm \mathrm{SD}$ (minimum-maximum, sample size)]. The mean number of hatched larvae per egg-case was $8.67 \pm 1.97(3-13, n=32)$ (see also WATANABE et al. (2020)). Mast white in colour; bag covered with mud and sand grains. When hatching, larvae make a hole to escape at the base of the mast. Total length of egg-case $6.98 \pm 1.41$ (4.39-10.63, $\mathrm{n}=32) \mathrm{mm}$.

Description of larva. First instar. General morphology similar to third instar; antenna and maxilla proportionally shorter and stouter than third instar. Ventral cuticular projections on nasale absent (Fig. 1I). Small to minute thoracic and abdominal sclerites present on third instar often indistinct, undetectable or absent. Basal segment of urogomphus bearing two long setae apically.

Primary chaetotaxy of head capsule. Frontale (Figs 2A, 3). Central part with three pairs of sensilla (FR1-3) slightly divergent posteriad; FR1 and FR3 minute seta, FR2 pore-like; FR1 close to frontal line, FR2 behind FR3. Pore-like sensillum FR4 and long seta FR6 situated mesally to antennal socket, FR6 posterolateral to FR4. Minute seta 


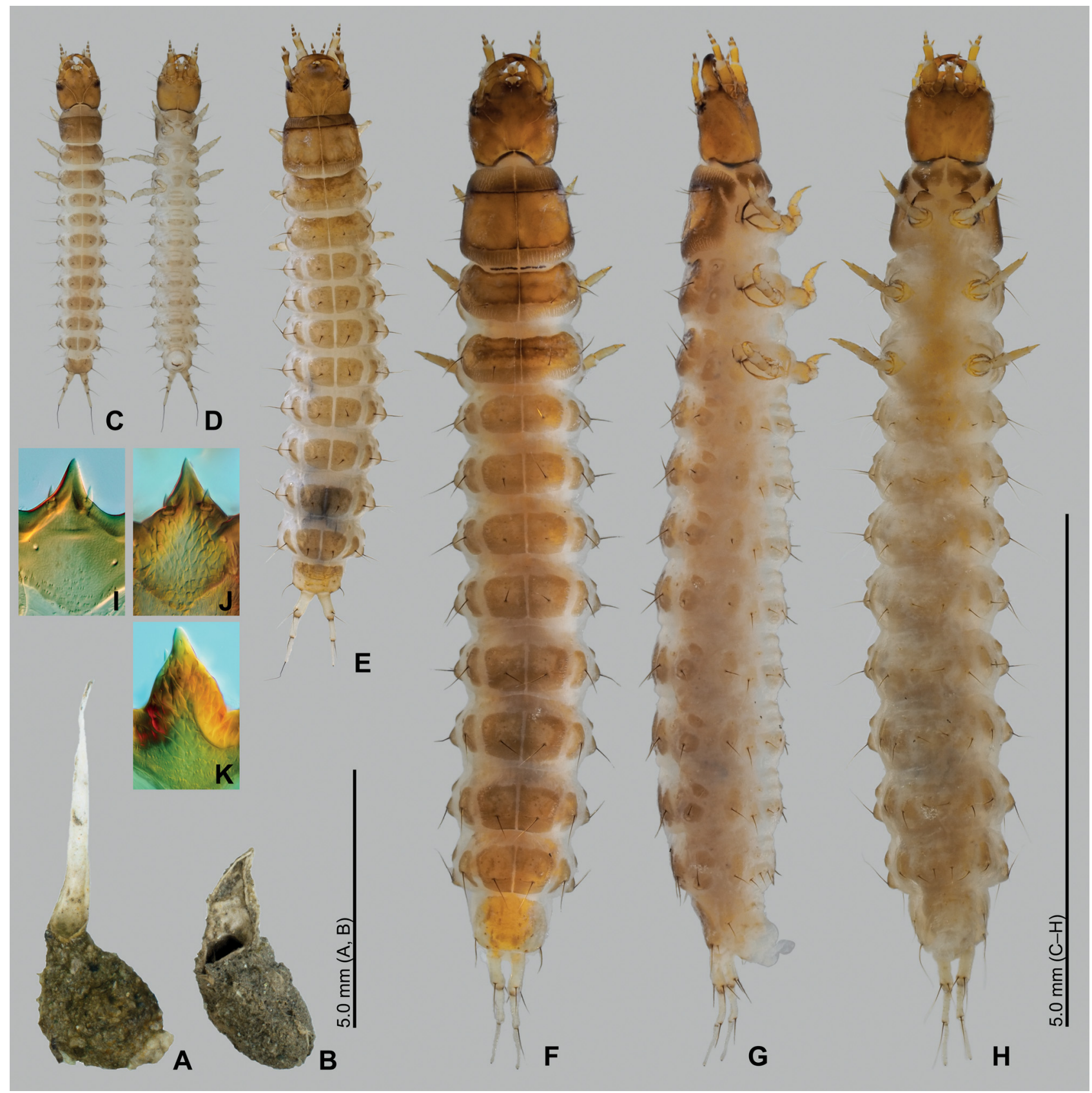

Fig. 1. Immature stages of Helophorus auriculatus Sharp, 1884. A, B - egg-case; C-H - whole larva; C, D - first instar, dorsal (C) and ventral (D) view; E - second instar, dorsal view; F-H - third instar, dorsal $(\mathrm{F})$, lateral $(\mathrm{G})$, ventral $(\mathrm{H})$ view; $\mathrm{I}-\mathrm{K}$ - ventral structure of nasale tooth (I - first instar, from ventral side; $\mathrm{J}$ - second instar, from dorsal side; $\mathrm{K}$ - third instar, from ventral side).

FR5 close to frontal line, posterior to FR6. FR7 minute seta, on inner margin of antennal socket. Rather short seta FR8 behind nasale, short seta FR9 posterolateral to FR8. Pore-like sensilla FR11, FR13, FR14 on epistome, forming oblique row; FR11 anterior to FR13 and FR14, FR13 between FR11 and FR14. Short seta FR10 situated laterally to FR13. Rather long seta FR12 anterior to FR10. FR15 absent. Nasale with group of six setae (gFR1); median two short, stout; lateral two minute. Epistomal lobe with five lanceolate to stout setae and two pore-like sensilla (gFR2); respective setae longer from inside to outside.

Parietale (Fig. 2). Dorsal surface with a group of five sensilla (PA1-5) forming slightly irregular oblique row in posterolateral part; PA3 pore-like, remaining four short setae. Minute sensillum-like structure between PA4 and PA5 often absent. Pore-like sensillum PA6 and short seta PA7 close to posterior end of frontal line; PA6 behind PA7. Rather long seta PA12 anteromesal to PA5. Seta PA8 extremely long, behind antennal socket. Minute seta PA9, pore-like sensillum PA10 and rather long seta PA11 behind lateral part of antennal socket; PA9 close to outer margin of antennal socket; PA10 between PA8 and PA9; PA11 behind PA10. PA16 rather long seta situated laterally between lateral-most stemma. PA13-15, PA17, PA18 placed laterally on midlength of parietale; PA13 and PA18 very long setae, PA14 rather long seta, PA15 and PA17 pore-like. PA13-15 on dorsolateral surface; PA13 close and dorsal to PA15; PA14 behind PA15; PA17 and PA18 on lateroventral surface, 


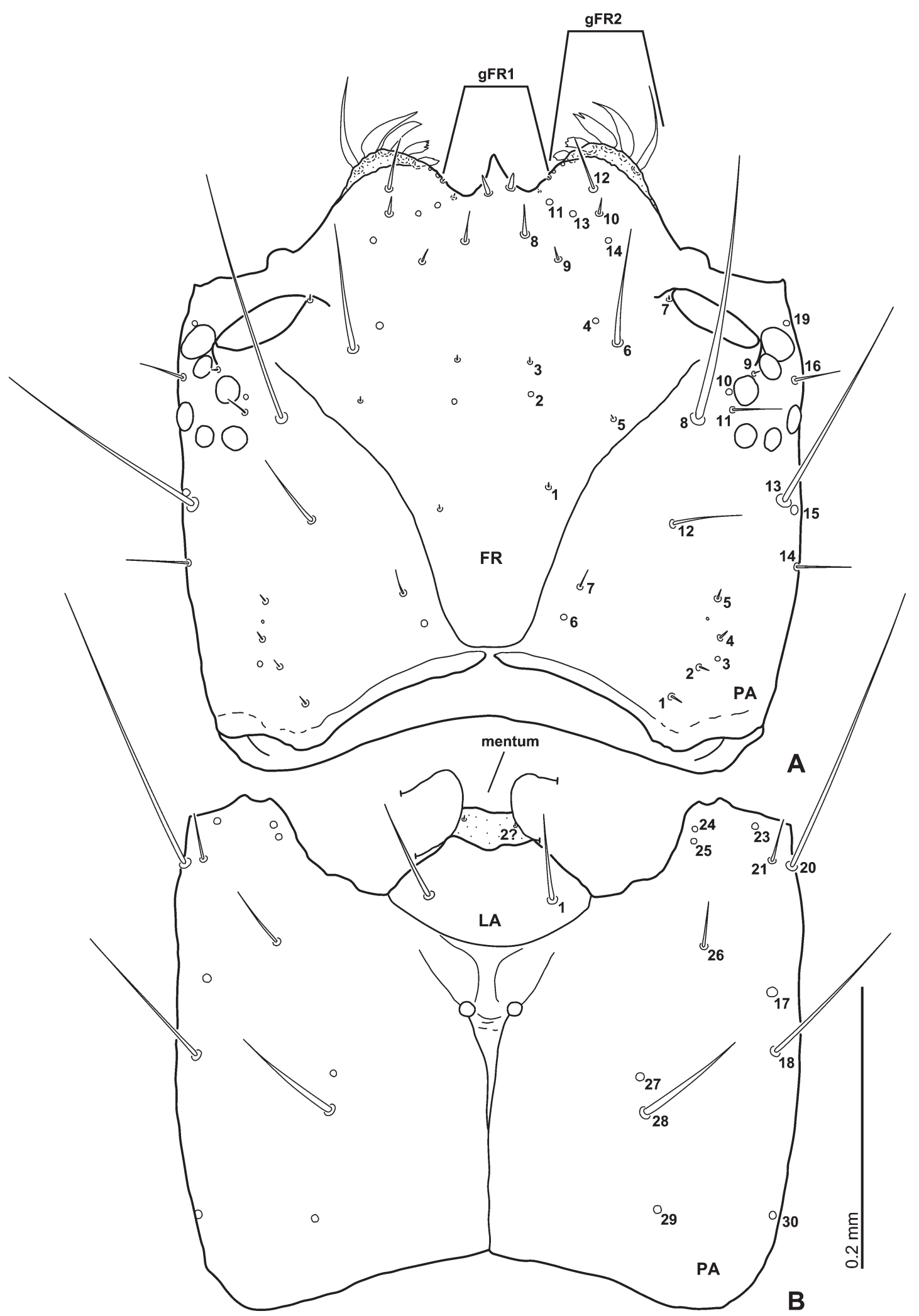

Fig. 2. First instar larva of Helophorus auriculatus Sharp, 1884. Head capsule, dorsal (A) and ventral (B) view.

PA18 behind PA17. PA19-21 and PA23 on anterior corner of head capsule; PA19 and PA23 pore-like, PA20 extremely long seta, PA21 rather short seta. PA19 and PA21 on lateral face; PA19 dorsal to PA20; PA21 and PA23 on ventral face, PA21 behind PA23. Pore-like sensilla PA24 and PA25 closely located, behind ventral mandibular articulation; PA24 anterior to PA25. PA22 absent. Rather short seta PA26 situated ventrally on anterior third, posterior to PA25. Pore-like sensillum PA27 and long, stout seta PA28 located ventrally on posterior two-fifths; pore-like sensillum PA29 posterior to PA28. Pore-like sensillum PA30 situated lateroventrally on posterior fifths. 


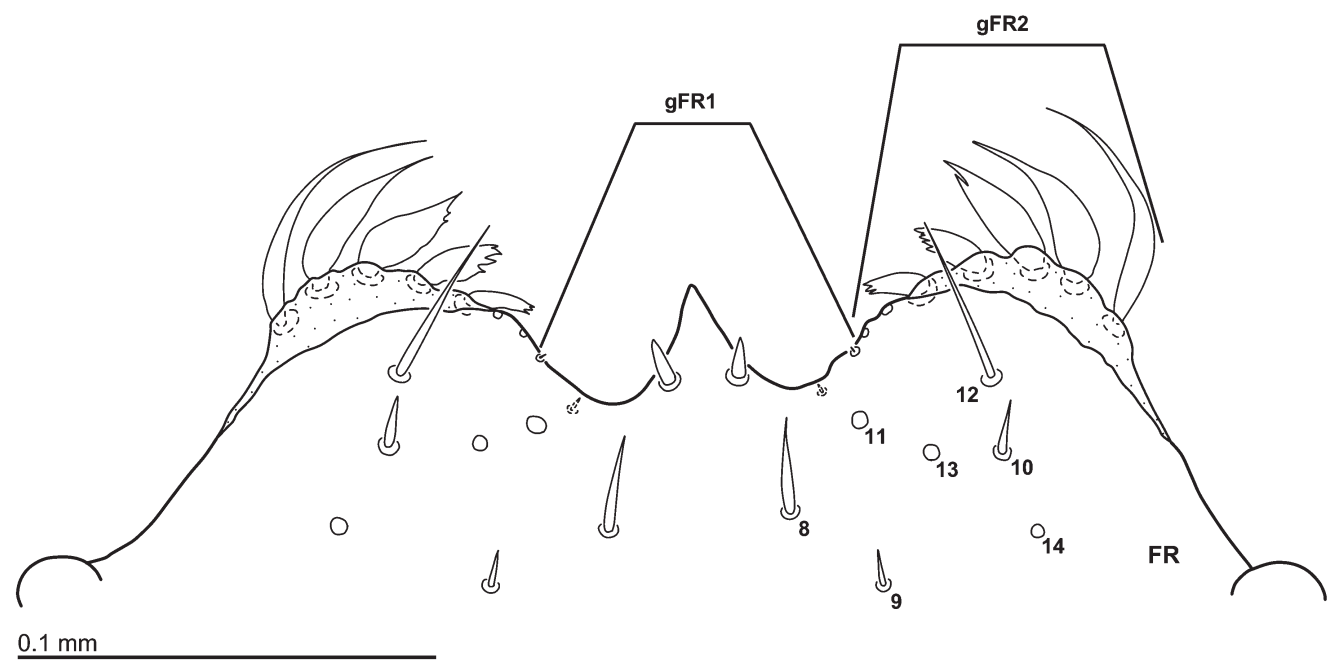

Fig. 3. First instar larva of Helophorus auriculatus Sharp, 1884. Anterior margin of head capsule, dorsal view.

Head appendages. Antenna (Figs 4A, B). Antennomere 1 with five pore-like sensilla (AN1-5). AN1 and AN2 situated dorsally on posterior fifth (AN1) and anterior third (AN2). AN3 situated laterally on anterior margin of sclerite. AN4 subapically on inner face of sclerite. AN5 ventrally on intersegmental membrane between antennomeres 1 and 2. Antennomere 2: AN6 situated dorsally on anterior third of sclerite. Setae AN8 and AN9 dorsolaterally on intersegmental membrane between antennomeres 2 and 3; AN8 rather short seta, lateral to minute seta AN9; AN10 and AN11 on inner face of membrane; AN10 short seta, dorsal to rather short seta AN11. AN7 undetectable (see description of third instar). Two sensoria present on lateral face of intersegmental membrane; SE1 conical, moderate in size, SE2 posterior to SE1, conical, much smaller than SE1. Antennomere 3 with group of apical sensilla (gAN) in apical membranous area.

Mandibles (Figs 4C-E). Three sensilla (MN1-3) forming oblique row at midlength of mandible; MN1 long seta on lateral face, MN2 and MN3 pore-like; MN3 close to incisors area, MN2 between MN1 and MN3. Pore-like sensillum MN4 and minute seta MN5 on dorsolateral face; MN4 anterior to MN2; MN5 anterior to MN4. Pore-like sensillum MN6 present on incisors area, very indistinct. Three sensillum-like structures present on subapical part of dorsal face; three sensillum-like structures ventrally on distal inner tooth.

Maxilla (Figs 4F-H). Cardo with rather short seta ventrally. Inner face of stipes with five stout, short setae (MX7-11). Pore-like sensillum MX3 on ventral part of inner face. Four sensilla (MX2, MX4-6) situated on lateroventral part. Pore-like sensillum MX2 and extremely long seta MX5 on posterior part, pore-like sensillum MX4 and long seta MX6 on subapical part. Palpomere 1: MX16 on inner face of palpomere 1. Three sensilla (MX12-14) on subapical part of sclerite; MX12 pore-like on lateral face; MX13 very long seta on lateroventral face; MX14 rather long seta ventrally on lateral part. Pore-like sensilla MX15 and MX17 on membrane behind inner appendage, MX17 dorsally, MX15 ventrally. Inner appendage with a group of apical sensilla
(gAPP). Palpomere 2 with two pores (MX18, MX19) and one minute seta (MX27). MX18 situated ventrally on apical margin of sclerite; MX27 ventrally at base; MX19 on inner face of intersegmental membrane between palpomeres 2 and 3. Palpomere 3 with four sensilla (MX20-23) on subapical part. MX20 pore-like, on lateral part; MX21 very short seta on inner face; MX22 pore-like, behind MX21; MX23 very short seta, on dorsal face. Palpomere 4 with three sensilla (MX24-26) and group of apical sensilla (gMX). MX24 very short seta, situated subbasally on inner face; MX25 digitiform dorsally on lateral face; MX26 pore-like ventrally on subapical part of lateral face.

Labium (Figs 2B, 4I-K). Submentum with one pair of long setae (LA1) laterally. Pair of minute setae (possible LA2) on membrane between submentum and mentum (Fig. 2B). Ventral surface of mentum with two pairs of sensilla (LA3, LA4); LA3 long seta, LA4 pore-like; LA3 lateral to LA4. Ventral surface of prementum with three pairs of sensilla (LA5-7); LA5 very short seta basally on mesal part; long seta LA6 and pore-like sensillum LA7 closely situated on lateral part. Pore-like sensillum LA8 dorsally on posterior membranous part of prementum. Four sensilla (LA9-12) dorsally on inner part of membrane between prementum and palpomere (anterior membranous area of prementum). LA10 short seta lateral to remaining three sensilla, possible LA9 and LA12 small, digitiform sensilla, anterior one may be LA12; LA11 pore-like. Ventral surface of palpomere 1 with very short seta LA13 at base. Pore-like sensillum LA14 dorsally on intersegmental membrane between palpomeres 1 and 2. Palpomere 2 with two subapical sensilla; LA15 pore-like on dorsolateral face; one additional sensillum digitiform, on lateroventral face. Several short sensilla of variable shape (gLA) on apical membranous area.

Second instar. Very similar to third instar; antenna proportionally slightly stouter than in third instar (Fig. 5A). Small to minute thoracic and abdominal sclerites present on third instar often indistinct, undetectable or absent. Chaetotaxy of head capsule similar to third instar larva; minute secondary seta, tentatively marked as AN7 present as in third instar (see Fig. 7A). 

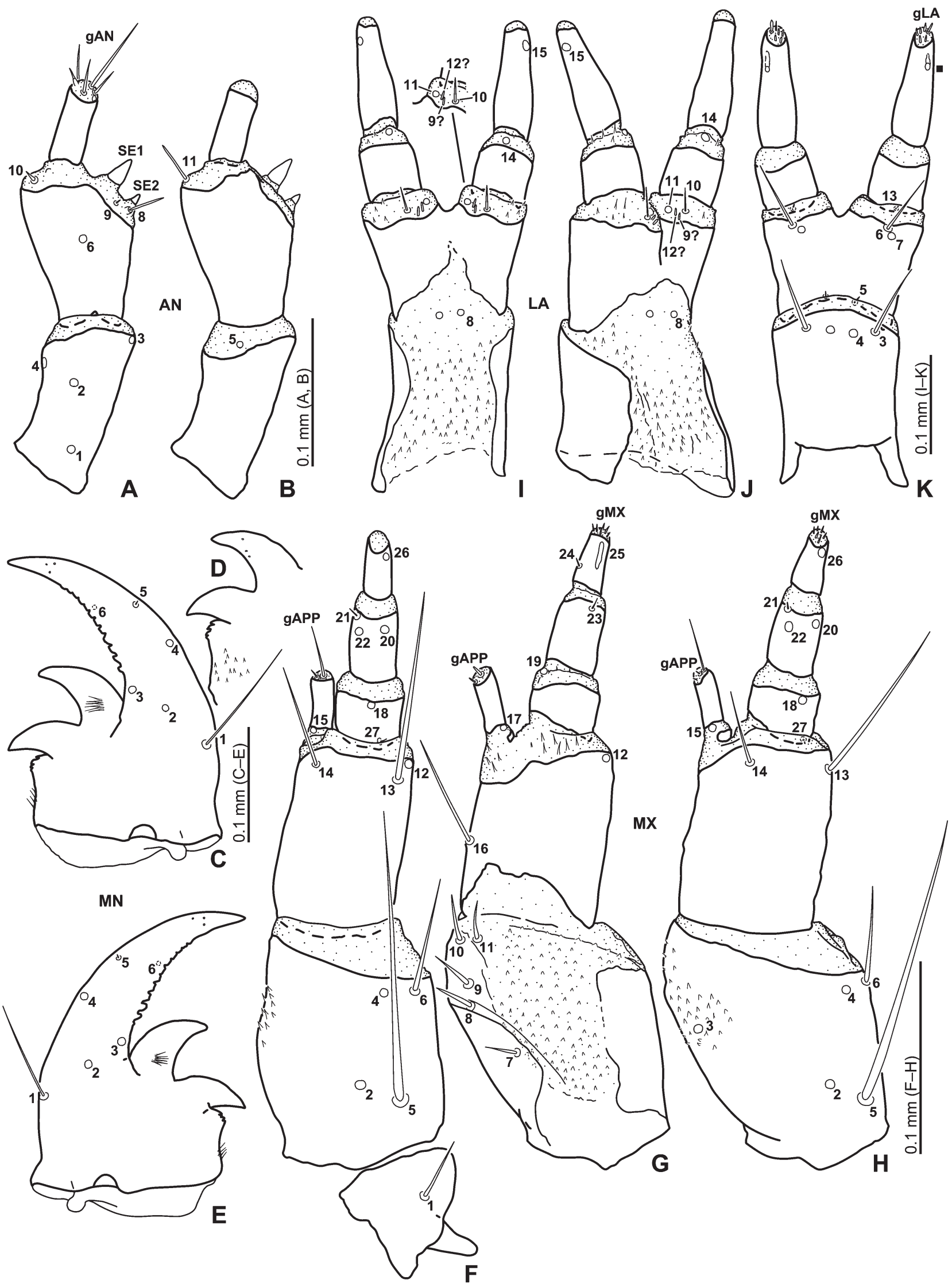

Fig. 4. First instar larva of Helophorus auriculatus Sharp, 1884. Head appendages. A, B - antenna, dorsal (A) and ventral (B) view; C-E - mandibles (C - right mandible, dorsal view, D - right mandible, ventral surface (drawn from dorsal), E - left mandible, dorsal view); F-H - maxilla ( F - ventral view, gMX omitted; G, H - maxilla, slightly modified by pressure of cover glass for examination, dorsal $(\mathrm{G})$ and ventral $(\mathrm{H})$ face, both drawn from dorsal view). I-K - labium, dorsal (I), dorsolateral (J), ventral (K) view. 


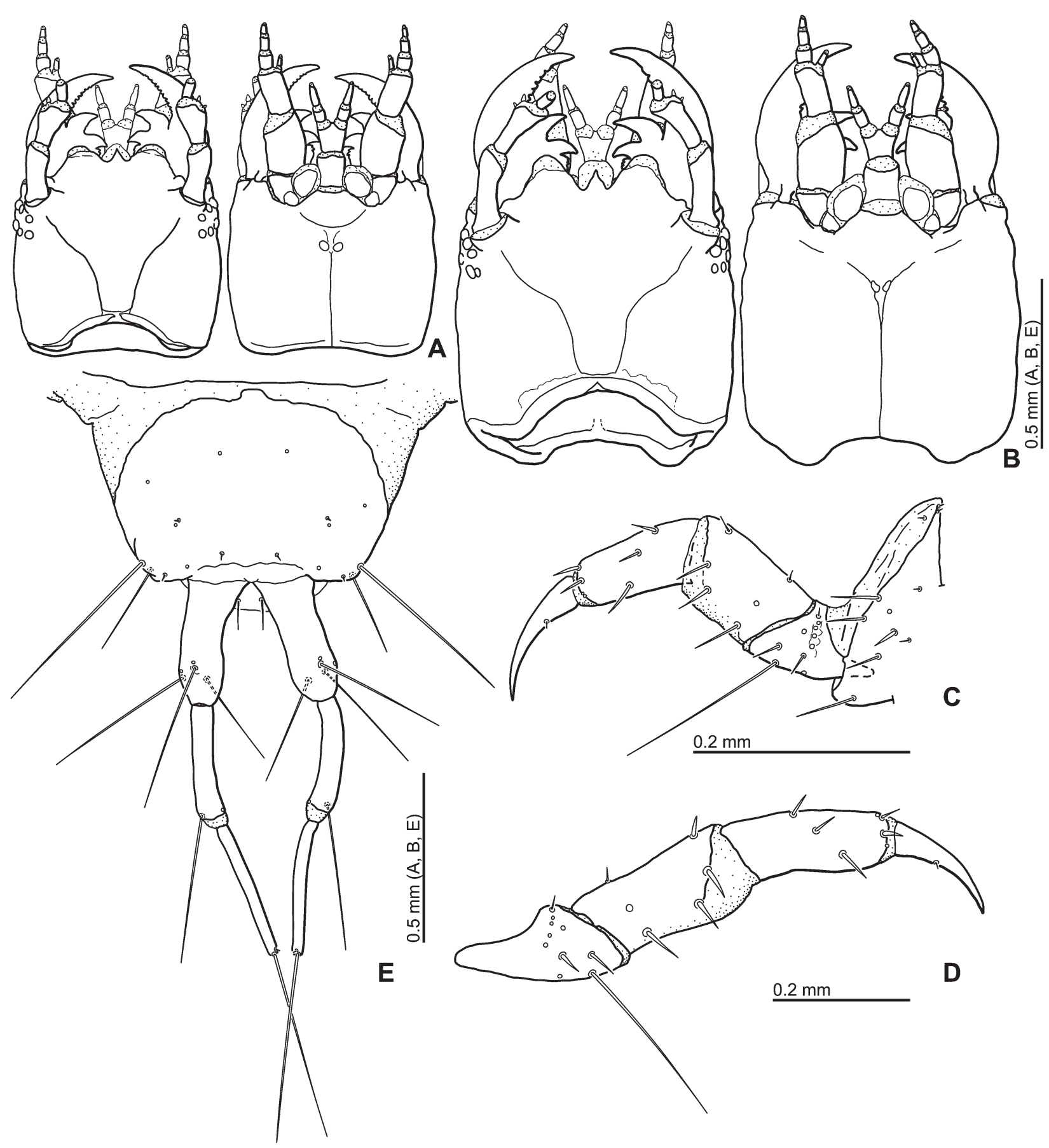

Fig. 5. Larvae of Helophorus auriculatus Sharp, 1884. A - head, second instar larva, dorsal (left) and ventral (right) view; B - head, third instar larva, dorsal (left) and ventral (right) view; C - posterior leg, first instar, anterior view; D - posterior leg, third instar, anterior view; E - abdominal apex, third instar, dorsal view.

Third instar. General morphology. Body (Figs 1E-G) slender; sclerites brownish dorsally, less pigmented ventrally; membranous parts whitish. Head. Head capsule (Fig. 5B) subpentagonal, almost parallel-sided. Cervical sclerites absent. Frontal lines complete, lyriform; coronal line absent (Figs 5B, 6A). Surface of head capsule smooth. Six stemmata on each anterolateral portion of head capsule. Posterior tentorial pits present on anteromedian part of head capsule; gular sulcus visible. Clypeolabrum symmetrical (Fig. 6C). Nasale with single large median projection with smooth lateral margins; ventral cuticular projections on nasale present, well developed (Fig. 1K). Epistomal lobe present, projected further than nasale, rounded anteriorly; apical part of epistomal lobe membranous.

Antenna (Fig. 7A) 3-segmented, slender. Surface of antenna smooth. Antennomere 1 as long as antennomeres 2 and 3 combined. Antennomere 2 widened apically as wide as antennomere 1. Antennomere 3 shortest and narrowest. Approximate ratios of length of antennomeres 1: 2: 3 (including intersegmental membrane) as follows: $1: 0.7: 0.3$ $(\mathrm{n}=1)$. Two antennal sensoria present (see description of chaetotaxy in detail).

Mandibles (Figs 7B, C) symmetrical; basal half distinctly wider than apical half; incisor area roughly 

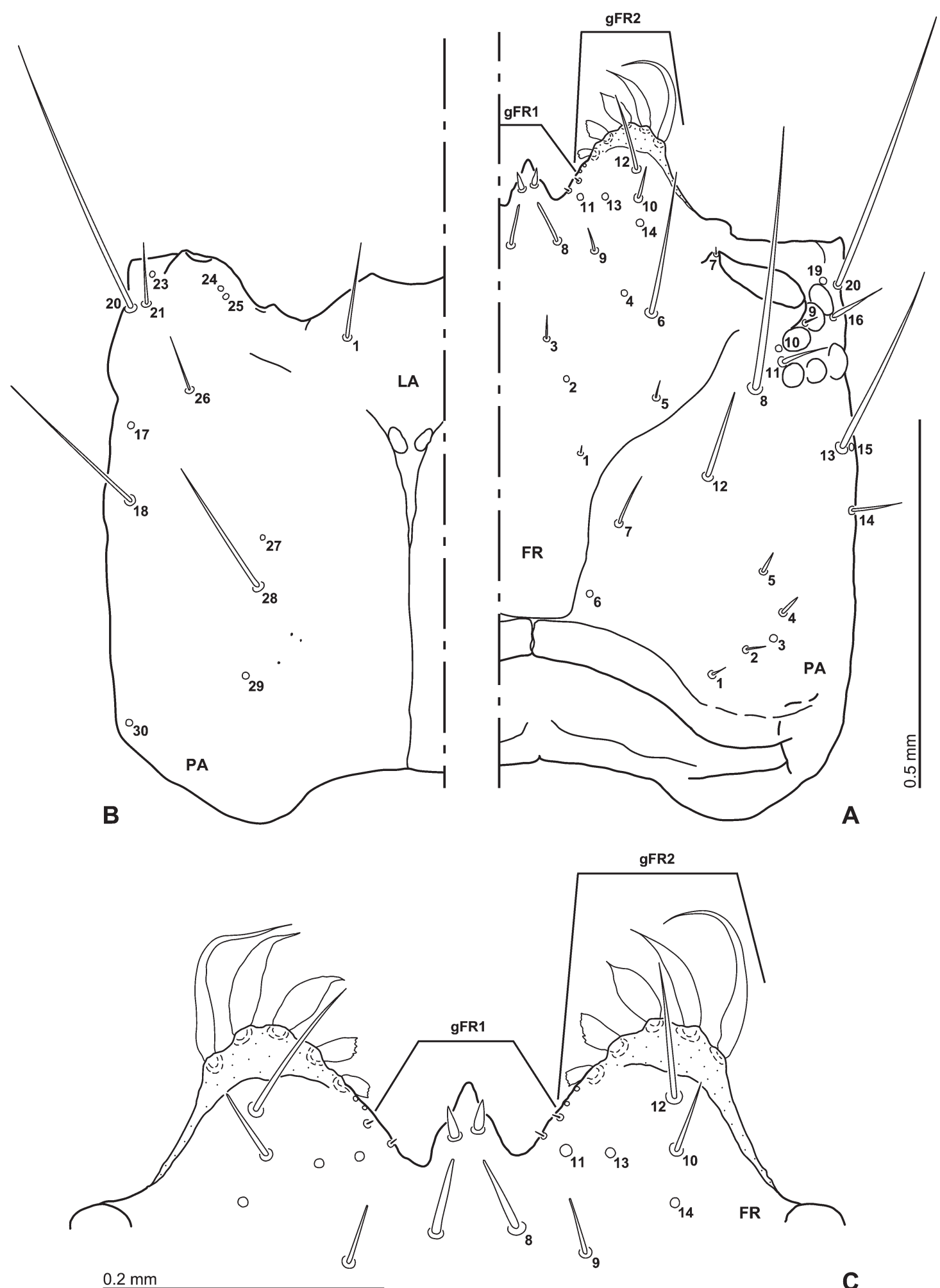

Fig. 6. Third instar larva of Helophorus auriculatus Sharp, 1884. A, B - head capsule, dorsal (A) and ventral (B) view; C - anterior margin of head capsule, dorsal view, ventral cuticular teeth omitted, see Fig. 1K.

serrated. Mandible with two inner teeth; basal one smaller than distal one; small aggregated teeth behind basal inner tooth. Groups of short, spine-like projections present dorsally on base of apical inner tooth (retinacular tuft) and on subbasal part of inner face (mandibular penicillus). Small projections present on inner part of ventral surface (Fig. 7C).
Maxilla (Fig. 7D) slender, 6-segmented, longer than antenna. Cardo large, subtriangular. Stipes the longest and widest, shorter than palpomeres 1-4 combined. Stipes not cylindrically sclerotized; dorsal surface of stipes mostly membranous (or very weakly sclerotized); posterior end of dorsal stipes undetectable. Dorsal surface with moderately densely arranged small teeth on membrane; inner 


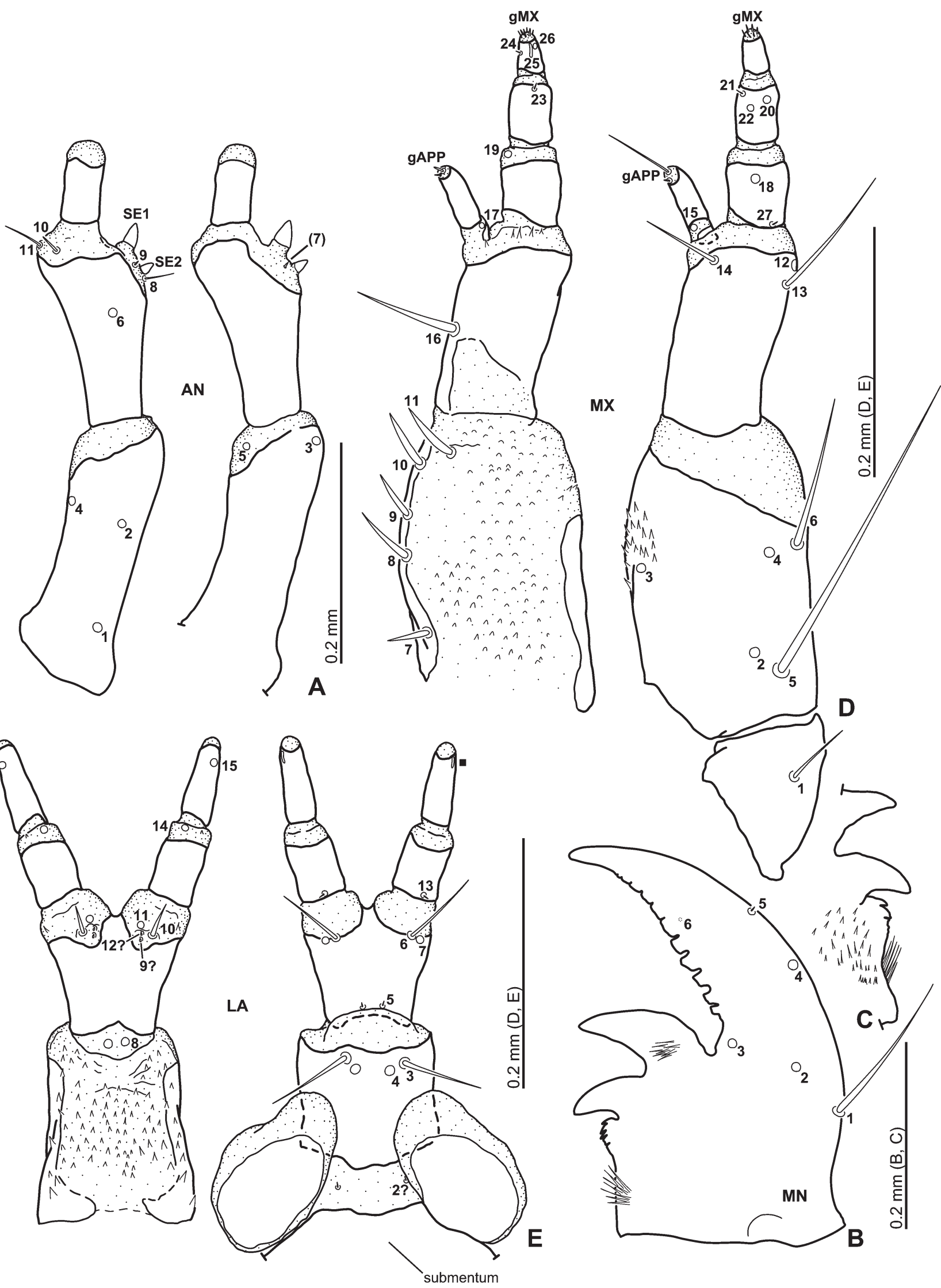

Fig. 7. Third instar larva of Helophorus auriculatus Sharp, 1884. A - antenna, dorsal (left) and ventral (right) surface, both drawn from dorsal view, gAN omitted; B - mandible, dorsal view; C - ventral surface of basal part of mandible; D - maxilla, dorsal (left) and ventral (right) surface, both drawn from dorsal view; E - labium, dorsal view (left) and labium and its adjacent structure, ventral view (right), gAN omitted. 
face with patch of small teeth on sclerite. Maxillary palpus moderately long, 4-segmented; all segments cylindrically sclerotized. Palpomere 1 longest and widest; dorsal surface membranous in posterior half. Inner process long, sclerotized, as long as palpomere 2. Intersegmental membrane between palpomeres 1 and 2 bearing a few cuticular teeth dorsally. Palpomere 2 similar to palpomere 3 in length, but wider than palpomere 2. Palpomere 4 the shortest and narrowest.

Labium (Fig. 7E) developed. Submentum fused with head capsule, transverse, subpentagonal. Mentum trapezoid. Dorsal surface of mentum membranous (or very weakly sclerotized); posterior end of dorsal surface undetectable; rather densely arranged cuticular teeth present on dorsal surface; lateral and ventral surface sclerotized. Prementum subpentagonal; posterior margin membranous dorsally; prementum sclerotized between labial palpi, connecting dorsal and ventral surfaces. Small cuticular teeth present laterodorsally on anterior membranous area of prementum. Ligula absent. Labial palpus moderately long, slender, palpomere 1 shorter and slightly wider than palpomere 2. Small cuticular tooth present laterodorsally on intersegmental membrane between palpomeres.

Thorax. Prothorax wider than head capsule, widened posteriorly. Proscutum formed by a large plate subdivided mesally by fine sagittal line. Ventral surface of prothorax with a pair of large prosternal sclerites (Fig. 8). One small subtriangular sclerite present mesally behind prosternal sclerite, between coxal cavities; a pair of rather small sclerites behind prosternal sclerite, connecting sclerite of outer margin of procoxal cavity; one small sclerite present posterolaterally to procoxa. Mesonotum with a large plate subdivided mesally by fine sagittal line and two pairs of very narrow, transverse sclerites anteromesally, anterior to large plate. Lateral face of mesothorax with two sclerites; anterior one situated on anterolateral portion, forming a ring around the mesothoracic spiracle; posterior one oval. Ventral surface of mesothorax with sclerites of variable

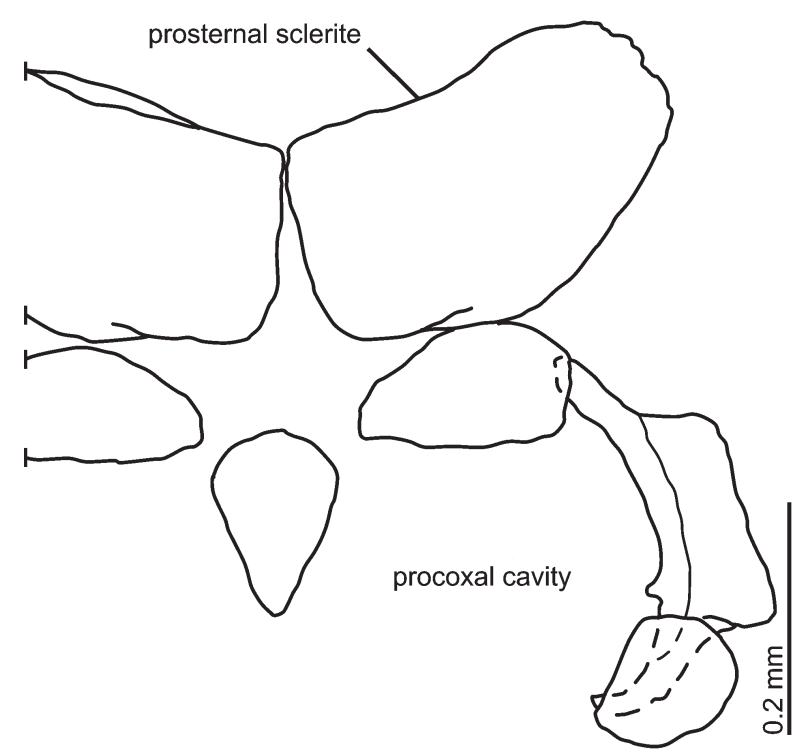

Fig. 8. Helophorus auriculatus Sharp, 1884, sclerites on ventral prothoracic segment of third instar larva. size; two oval sclerites present mesally; anterior one smaller than posterior one; small oval sclerite present laterally to anterior mesal sclerite; associated sclerite of mesocoxa similar to prothoracic one but smaller; one oval sclerite posterolateral to mesocoxa. Metathorax similar to mesothorax with the following two exceptions: narrow mesal sclerites absent on dorsal surface; spiracle absent, thus the lateral sclerite is oval, not forming ring.

Legs (Fig. 5D) well developed, visible from dorsal view; meso- and metacoxae situated on lateral part of ventral surface, widely separated than procoxae. Ventral face of femur more or less membranous, borderline between membrane and sclerite unclear.

Abdomen. Abdomen with 9 well-developed segments (Figs $1 \mathrm{~F}-\mathrm{H}$ ), segments not subdivided by transverse folds. Segment 1 with several sclerites: dorsal surface with large sclerite present mesally, subdivided by sagittal line; a pair of moderately large sclerites lateral to large sclerite; a pair of small sclerites present anterolaterally. Lateral surface with two sclerites; anterior one smaller than posterior one. Ventral face with 7 sclerites; lateral two pairs oval, median three transverse. Segments 2-7 similar to segment 1, but a minute sclerite present anteromesally to spiracle; anterior two mesal transverse sclerites of ventral face reduced to one anterior very narrow sclerite and small sclerites behind the narrow sclerite. Segment 8 similar to segment 7 but spiracle situated dorsally on posterolateral part; minute sclerite on dorsolateral face absent. Abdominal apex not forming a spiracular atrium (Fig. 5E); segment 9 with large, oval plate dorsally, lateral face with one small sclerite; ventral face with small sclerites; a pair of long three-segmented urogomphi present, bearing several long setae. Basal segment of urogomphus bearing three long setae apically. Segment 10 on ventral face of segment 9.

Chaetotaxy. Chaetotaxy of head capsule (Fig. 6) and head appendages (Fig. 7) very similar to first instar except that minute secondary seta, tentatively marked as AN7 present ventrally close to sensorium SE2 (Fig. 7A; see also Remarks).

Description of pupa. Colour. Transparent milky white with reddish eyes (Figs 9D-F). Body (Fig. 9) elongate with styli bearing apical seta.

Head deflexed ventrally; head and appendages covered by pronotum in dorsal view. Head appendages partly visible in ventral view; antenna short; mandibles wide and blunt at apex; maxillary palpus slender. Surface of head capsule bearing three pairs of styli close to inner margin of each eye.

Thorax. Pronotum transverse, evenly and weakly convex, bearing eight pairs of styli. Two pairs mesally; one pair on anterior margin and one on posterior margin. Six pairs on lateral margins; three pairs on anterior corner; one pair at midlength; two pairs on posterior corner. Meso- and metanotum with one pair of styli on each median portion. Legs slender, partly visible in dorsal view. Forewing elongate oval, with numerous longitudinal striae; hindwing similar to forewing in size.

Abdomen with nine segments, attenuated towards apex, but anterior third to anterior half almost subparallel-sided. 

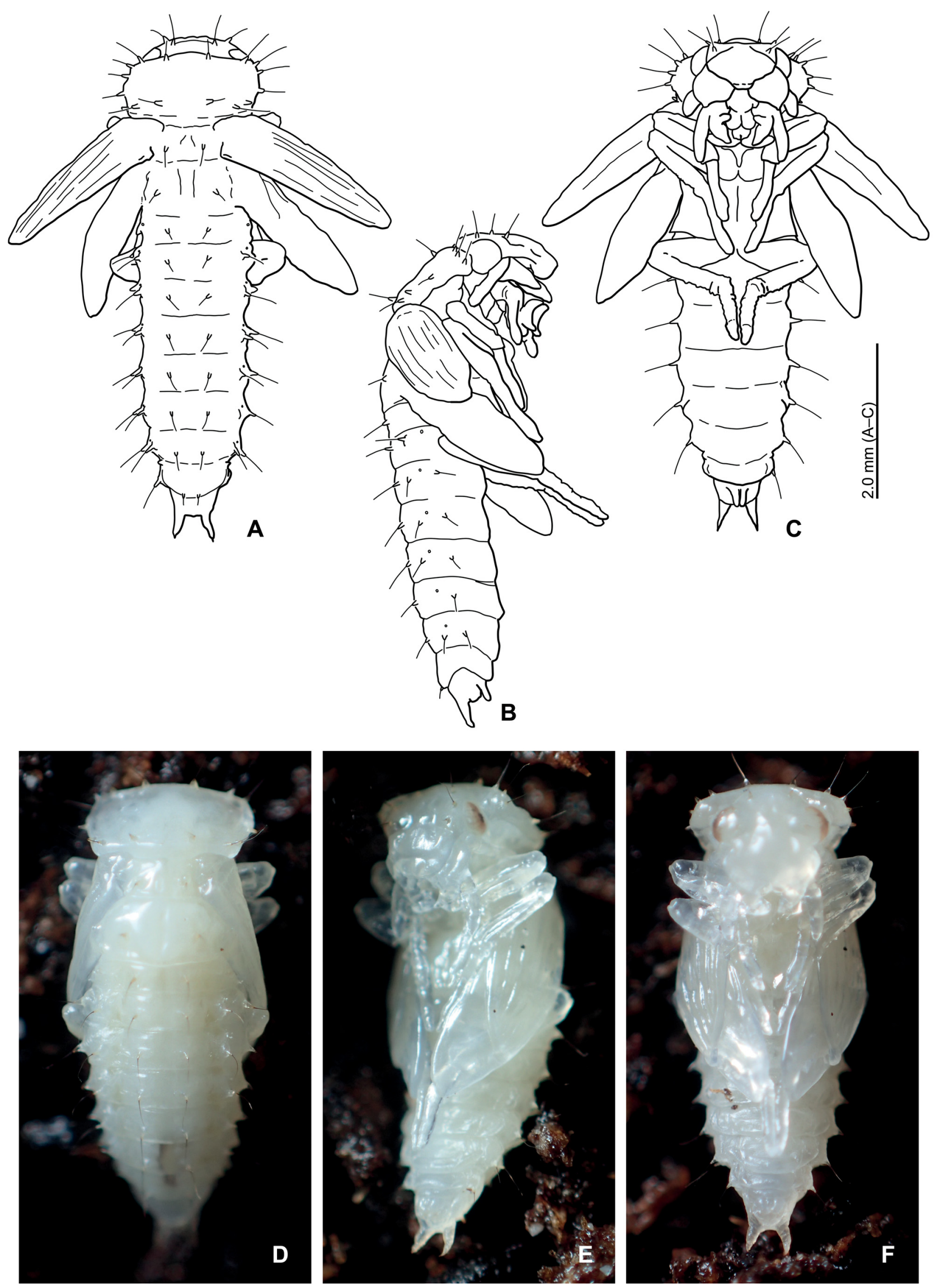

Fig. 9. Pupa of Helophorus auriculatus Sharp, 1884. A - dorsal view; B - lateral view; C - ventral view. Some styli missing. D-F - living individuals in pupal chamber, dorsal (D), lateroventral (E), and ventral (F) view. 
Abdominal segments bearing styli on dorsal and lateral faces. Segment 1 transverse, with one pair of styli on disc, but it is possible that a lateral pair is missing. Segments 2 to 7 transverse, with three pairs of styli; one close to midline, two lateral. Segment 8 with two pairs of styli; one on median part, one on lateral part. Segment 9 with well developed, non -articulated urogomphi sharply pointed at apex. Segments 1 to 7 bearing a pair of spiracles on each side.

Biology. We reared the larvae of $H$. auriculatus using only Tubifex worms or chironomid larvae for their diet. This stands in contrast to the reports of Chinese population of $H$. auriculatus as pests of winter wheat (ANGUS \& JIA 2015). Based on our rearings, we may confirm that the larvae of Japanese population of this species are carnivorous. For detailed biological information, see WATANABE et al. (2020).

Remarks. In helophorid larval antennae, there are two sensoria and two setae (FIKÁČEK et al. 2008) on the outer face of the intersegmental membrane between antennomeres 2 and 3. Arrangement of the antennal sensilla of $H$. auriculatus is nearly identical to that of $H$. (H.) liguricus, $H$. (Lihelophorus) yangae and $H$. (L.) lamicola (FIKÁČEK et al. 2008, ANGUS et al. 2016). However, one secondary seta was present in the area of the second and third instar larvae (Figs 7A, B). Although this seta is not a primary sensillum, we have tentatively marked it as AN7 (in parentheses; Fig. 7B) based on its position.

The dorsal surfaces of the stipes and mentum of $H$. auriculatus were 'soft' as described by ANGUs (1992). We illustrated and described these structures as membranous to distinguish them from sclerites (Figs 4 F-H, I-K, 7D, E) even though it is possible that are weakly sclerotized. This type of modification ('soft' dorsal surface) is unusual within the Hydrophiloidea. For example, membranous or weakly sclerotized dorsal surface of the mentum has been reported in the hydrophilid genus Laccobius Erichson, 1837 and the family Epimetopidae (ARCHANGELSKY 1997; FIKÁČEK et al. 2011, 2018) which have a reduced mentum.

\section{Discussion}

Larval morphology. The larvae of the subgenus Gephelophorus herein described were superficially similar to those of other subgenera. Although this similarity makes Gephelophorus identification difficult, several characters of the head can be used to distinguish among larvae. (1) The nasale is symmetrical and the parietale is smooth in all subgenera excluding Lihelophorus Zaitzev, 1908. (2) Serrations on the lateral margin of the nasale are absent in Gephelophorus, Lihelophorus and Rhopalohelophorus Kuwert, 1886, but present in Eutrichelophorus Sharp, 1915 and in some species of Empleurus Hope, 1838, Helophorus Fabricius, 1775, and Trichohelophorus Kuwert, 1886 (intraspecific variation and variation between instars were observed in Trichohelophorus; ANGUs 1992). The nasale of Kyphohelophorus Kuwert, 1886 is exceptionally composed of strong teeth (ANGUS 1992). (3) Ventral projections (teeth) on the nasale are present in the second and third instar larvae of Gephelophorus, Eutrichelophorus and Helophorus, and in some species of Rhopalohelophorus, whereas they are absent in Empleurus, Kyphohelophorus and Trichohelophorus
Table 1. Comparison of primary chaetotaxic characters of Gephelophorus larvae and those of Helophorus and Lihelophorus based on $H$. $(H$.) liguricus Angus, 1970, H. (L.) lamicola Zaitzev, 1908 and H. (L.) yangae Angus et al., 2016 described by ANGus et al. (2016). Based on first instar larvae for all taxa compared.

\begin{tabular}{llll}
\hline & Gephelophorus & Helophorus & Lihelophorus \\
\hline FR8 & $\begin{array}{l}\text { close to each } \\
\text { other }\end{array}$ & $\begin{array}{l}\text { close to each } \\
\text { other }\end{array}$ & $\begin{array}{l}\text { close to each other / } \\
\text { widely separated }\end{array}$ \\
\hline FR6 & long & minute & long \\
\hline PA7 & short & minute & long/short \\
\hline PA8 & long and stout & long and stout & long and fine \\
\hline PA12 & rather short & rather short & rather short / long \\
\hline PA13 & long and stout & long and fine & long and fine \\
\hline MX5 & much longer & much longer & much longer than \\
& than MX6 & than MX6 & $\begin{array}{l}\text { or same length } \\
\text { as MX6 }\end{array}$ \\
\hline MX7-11 & short & short & short / long \\
\hline MX13 & long & rather short & short \\
\hline
\end{tabular}

(ANGus 1992, ANGus et al. 2016) (the second and third instar larvae of Lihelophorus are unknown (ANGUS et al. 2016)). (4) A mandibular retinacular tuft is present in Gephelophorus, Helophorus, Lihelophorus and Rhopalohelophorus, but absent in Empleurus, Eutrichelophorus, Kyphohelophorus and Trichohelophorus.

ANGUS et al. (2016) described the chaetotaxy of the larval head for the subgenera Helophorus (one species: H. liguricus) and Lihelophorus (two species: H. lamicola and $H$. yangae) and briefly mentioned chaetotaxy of other species. Chaetotaxy of larval head of $H$. auriculatus is similar to those species, but $H$. auriculatus can be distinguished by several features, most notably the length and shape of the sensilla on the frontale, parietale and maxilla (Table 1).

Morphological transformations between larval instars. Morphological transformations between instars have been studied in several groups of the Hydrophilidae (e.g., BYTTEBIER \& TORRes 2009, Minoshima \& HAYASHI 2011). These studies have revealed that the antennae and maxillae are proportionally stouter in the first instar but proportionally narrower in later instars. Additionally, they have shown that the number of setae of the head capsule and/or its appendages increases. The larvae of $H$. auriculatus show similar modifications in the proportions of head appendages; however, secondary sensilla do not occur in later instars, except for a seta adjacent to SE1 on the outer face of the intersegmental membrane between antennomeres 2 and 3 (tentatively marked as AN7; see Remarks).

The number of ventral cuticular projections (teeth) on the nasale are considered as a subgeneric diagnostic character in Helophorus larvae (ANGus 1992). This character has been suggested to be variable between first and later instars (Angus et al. 2016). Our examinations of $H$. auriculatus confirmed this speculation: ventral projections of the nasale were absent in the first instar (Fig. 1I), but well developed in the second and third instars (Figs 1J, K). This character is diagnostic for second and third instar larvae but not for the first instar larva.

Pupal morphology. Little information is available on helophorid pupae; the pupa of H. (Helophorus) aquaticus 
was described by Bøving \& HenRIKSEn (1938) and that of $H$. (Rhopalohelophorus) orientalis by ARCHANGELSKY (1997). The pupa of H. auriculatus was similar to these two previously described species, and the number of styli on respective segments was identical. ARCHANGELSKY (1997) noted variation in the number of the styli on the pronotum (14-16); the pupal specimen of $H$. auriculatus examined here had 16 styli on the pronotum (Figs 9A-C).

\section{Key to families of larvae of Japanese Hydrophiloidea}

All families of Hydrophiloidea except Epimetopidae are recorded from Japan (HANSEN 1999, KitANO et al. 2019). Although the larvae of Japanese species of Georissidae, Hydrochidae and Spercheidae are not described, larvae of the Japanese hydrophiloid families may be identified using the following key (adapted from RicHMOND 1920, BøVING \& HENRIKSEN 1938, ARCHANGELSKY 1997):

1. Abdominal segment 9 complete (Fig. 5E; see also fig. 6A, C in Archangelsky 1997 for Georissidae, which has slightly reduced segment 9), thus segments 8 to 10 not forming spiracular atrium; antenna with two sensoria (SE1 and SE2) on outer face of the intersegmental membrane between antennomeres 2 and 3 (Figs 4A, 7A). 2

- Abdominal segment 9 modified as part of the spiracular atrium, not or only partly visible from dorsal view, thus segments 8 to 10 forming spiracular atrium (spiracular atrium highly reduced in hydrophilid genus Berosus Leach, 1817, e.g., fig. 5D in Minoshima \& Hayashi 2015); antenna with one sensorium (SE1) on outer face of the intersegmental membrane between antennomeres 2 and 3 (often SE1 is reduced in size and very small; e.g., fig. 53A in Minoshima \& Hayashi 2011). ......... 3

2. Legs well developed, five-segmented (Figs 5C, D); urogomphi well developed, long, three-segmented (Fig. 5E).

Helophoridae

- Legs reduced, minute, three-segmented (fig. 8A in Archangelsky 1997); urogomphi reduced.

Georissidae

3. Inner tooth of mandible situated close to mandibular apex, thus mandibular apex looks bifid; inner face of stipes strongly extending anteromesally, forming well developed, large inner lobe (lacinia); labium developed; mentum fused with prementum, forming plate-like structure (Archangelsky 1997, 2001; Fikáček 2019a); legs five-segmented, very long. ........

Spercheidae

- Inner tooth of mandible situated on median part, thus mandibular apex simple; inner face of stipes not extending anteromesally or weakly extending anteromesally, forming small inner lobe (lacinia) (see Archangelsky 1997); labium well developed or reduced; if labium well developed, mentum not fused with prementum (rarely fused but not in Japanese species); legs variable, minute to long. .................. 4

4. Submentum fused with head capsule (Figs 2B, 6B); antennomere 1 variable in length but never very long and stout (Archangelsky 1997, Minoshima \& Hayashi 2011); second segment of the labial palpus without a large sensorium; legs usually well developed in aquatic species, moderately to highly reduced in some terrestrial groups (Arriaga-Varela et al. 2017, Archangelsky 2018, Minoshima 2019)

Hydrophilidae

- Submentum not fused with head capsule; antennomere 1 very long and stout; second segment of labial palpus with two large sensoria of almost same size as the second palpomere; legs well developed, fivesegmented (Richmond 1920, Archangelsky 1997, Fikáček 2019b). .................................. Hydrochidae

\section{Acknowledgements}

We are grateful to the Tsukuba Environment Forum (Tsukuba, Japan), who granted R. Watanabe permissions to work in the study site. We thank Martin Fikáček (National Museum, Prague, Czech Republic) for his valuable comments on the draft. Miguel Archangelsky (Universidad Nacional de la Patagonia San Juan Bosco, Esquel, Argentina) and Robert B. Angus (The Natural History Museum, London, United Kingdom) are acknowledged for their constructive criticism on the manuscript. This study was partly supported by JSPS KAKENHI Grant Number JP17K15187 to Y. Minoshima.

\section{References}

ANGUS R. B. 1973: Habitats, life histories and immature stages of Helophorus F (Coleoptera-Hydrophilidae). Transactions of the Royal Entomological Society of London 125(1): 1-26.

ANGUS R. B. 1992: Insecta, Coleoptera, Hydrophilidae, Helophorinae. Süßwasserfauna von Mitteleuropa, Band 20/10-2. Gustav Fischer Verlag, Stuttgart, Jena, New York, xi + 144 pp.

ANGUS R. B. \& JIA F.-L. 2015: Helophorus auriculatus, a further species whose larvae are pests of wheat. Latissimus 36: 15.

ANGUS R. B., JIA F.-L., CHEN Z.-N., ZHANG Y., VONDRÁČEK D. \& FIKÁČEK M. 2016: Taxonomy, larval morphology and cytogenetics of Lihelophorus, the Tibetan endemic subgenus of Helophorus (Coleoptera: Hydrophiloidea). Acta Entomologica Musei Natioalis Pragae 56(1): 109-148.

ARCHANGELSKY M. 1997: Studies on the biology, ecology, and systematics of the immature stages of New World Hydrophiloidea (Coleoptera: Staphyliniformia). Bulletin of the Ohio Biological Survey, New Series 12: 1-207.

ARCHANGELSKY M. 2001: A new neotropical species of Spercheus Kugelann, and its larval stages (Coleoptera, Hydrophiloidea: Spercheidae). Studies on Neotropical Fauna and Environment 36(3): 199-204.

ARCHANGELSKY M. 2018: Larval chaetotaxy and morphometry of Oosternum costatum (Coleoptera: Hydrophilidae: Sphaeridiinae, Megasternini) and a discussion of larval characters with phylogenetic relevance. Acta Entomologica Musei Nationalis Pragae 58(2): 499-511.

ARRIAGA-VARELA E., SEIDEL M., DELER-HERNÁNDEZ A., SENDEROV V. \& FIKÁČEK M. 2017: A review of the Cercyon Leach (Coleoptera, Hydrophilidae, Sphaeridiinae) of the Greater Antilles. ZooKeys 681: 39-93.

BØVING A. G. \& HENRIKSEN K. L. 1938: The developmental stages of the Danish Hydrophilidae (Ins., Coleoptera). Videnskabelige Meddelelser fra Dansk Naturhistorisk Forening i København 102: 27-162.

BYTTEBIER B. \& TORRES P. L. M. 2009: Description of the preimaginal stages of Enochrus (Hugoscottia) variegatus (Steinheil, 1869) and E. (Methydrus) vulgaris (Steinheil, 1869) (Coleoptera: Hydrophilidae), with emphasis on larval morphometry and chaetotaxy. Zootaxa 2139: 1-22. 
FIKÁČEK M. 2019a: 18. Hydrochidae Thomson, 1859. Pp. 258-264. In: LAWRENCE J. F. \& ŚLIPIŃSKI A. (eds.): Australian Beetles Volume 2, Archostemata, Myxophaga, Adephaga, Polyphaga (part). CSIRO Publishing, Melbourne, vii + 784 pp.

FIKÁČEK M. 2019b: 20. Hydrophilidae Latreille, 1802. Pp. 271-337. In: LAWRENCE J. F. \& ŚLIPIŃSKI A. (eds.): Australian Beetles Volume 2, Archostemata, Myxophaga, Adephaga, Polyphaga (part). CSIRO Publishing, Melbourne, vii + 784 pp.

FIKÁČEK M., ARCHANGELSKY M. \& TORRES P. L. M. 2008: Primary chaetotaxy of the larval head capsule and head appendages of the Hydrophilidae (Coleoptera) based on larva of Hydrobius fuscipes (Linnaeus, 1758). Zootaxa 1874: 16-34.

FIKÁČEK M., BARCLAY M. V. L. \& PERKINS P. D. 2011: Two new species of the Epimetopus mendeli species group and notes on its adult and larval morphology (Coleoptera: Hydrophiloidea: Epimetopidae). Acta Entomologica Musei Nationalis Pragae 51(2): 477-504.

FIKÁC̆EK M., MINOSHIMA Y. N. \& JÄCH M. A. 2018: Larval morphology of Yateberosus, a New Caledonian endemic subgenus of Laccobius (Coleoptera: Hydrophilidae), with notes on parallel evolution of 'Berosus-like' larval morphology in Hydrophiloidea. Acta Entomologica Musei Nationalis Pragae 58(1): 195-206.

FIKÁČEK M., PROKIN A., ANGUS R. B., PONOMARENKO A., YUE Y. L., REN D. \& PROKOP J. 2012a: Revision of Mesozoic fossils of the helophorid lineage of the superfamily Hydrophiloidea (Coleoptera: Polyphaga). Acta Entomologica Musei Nationalis Pragae 52(1): 89-127.

FIKÁČEK M., PROKIN A., ANGUS R. B., PONOMARENKO A., YUE Y. L., REN D. \& PROKOP J. 2012b: Phylogeny and the fossil record of the Helophoridae reveal Jurassic origin of extant hydrophiloid lineages (Coleoptera: Polyphaga). Systematic Entomology 37(3): 420-447.
HANSEN M. 1999: World Catalogue of Insects 2: Hydrophiloidea (s. str.) (Coleoptera). Apollo Books, Amsterdam, 416 pp.

KITANO T., TAHIRA Y. \& KOHNO H. 2019: Discovery of the family Spercheidae (Coleoptera, Hydrophiloidea) from Japan, with redescription of Spercheus stangli Schwarz et Barber, 1917. Elytra, New Series 9(2): 291-295.

MINISTRY OF THE ENVIRONMENT OF JAPAN 2019: [Ministry of the Environment Red List 2019]. Available online: http://www.env. go.jp/press/files/jp/110615.pdf (accessed on 29 January, 2020) (In Japanese).

MINOSHIMA Y. N. 2019: First known larva of omicrine genus Psalitrus d'Orchymont (Coleoptera, Hydrophilidae). Deutsche Entomologische Zeitschrift 66(1): 107-118.

MINOSHIMA Y. \& HAYASHI M. 2011: Larval morphology of the Japanese species of the tribes Acidocerini, Hydrobiusini and Hydrophilini (Coleoptera: Hydrophilidae). Acta Entomologica Musei Nationalis Pragae 51 (supplementum): 1-118.

MINOSHIMA Y. N. \& HAYASHI M. 2015: Description of the larval stages of berosine genera Berosus and Regimbartia (Coleoptera, Hydrophilidae) based on Japanese B. japonicus and R. attenuata. Acta Entomologica Musei Nationalis Pragae 55(1): 47-83.

RICHMOND E. A. 1920: Studies on the biology of the aquatic Hydrophilidae. Bulletin of the American Museum of Natural History 42: 1-94, pls. 1-16.

SHIRAYAMA Y., KAKU T. \& HIGGINS R. P. 1993: Double-sided microscopic observation of meiofauna using an HS-slide. Benthos Research 44: 41-44 (In Japanese with English title and abstract).

WATANABE R., MATSUSHIMA R. \& YODA G. 2020: Life history of the endangered Japanese aquatic beetle Helophorus auriculatus (Coleoptera: Helophoridae) and implications for its conservation. Journal of Insect Conservation 10.1007/s10841-019-00214-1. 